NBER WORKING PAPER SERIES

\title{
TRANSPARENCY AND INTERNATIONAL INVESTOR BEHAVIOR
}

\author{
R. Gaston Gelos \\ Shang-Jin Wei \\ Working Paper 9260 \\ http://www.nber.org/papers/w9260 \\ NATIONAL BUREAU OF ECONOMIC RESEARCH \\ 1050 Massachusetts Avenue \\ Cambridge, MA 02138 \\ October 2002
}

The authors wish to thank Philippe Bacchetta, Andrew Berg, Patrick Bolton, Tito Cordella, Douglas Gale, Philippe Martin, Paolo Mauro, Alessandro Prati, David Robinson, Nouriel Roubini, Antonio Spilimbergo, Jiang Wang, and seminar participants at the IMF for helpful discussions, Torbjörn Becker, Przemek Gajdeczka, Hunter Monroe, and Anthony Richards for detailed comments on earlier drafts, and Peter Allum for sharing data. Nese Erbil and Chi Nguyen provided excellent research assistance. The views in the paper are the authors' own and may not reflect those of the IMF or any other organization that they are or have been associated with.

(C) 2002 by R. Gaston Gelos and Shang-Jin Wei. All rights reserved. Short sections of text, not to exceed two paragraphs, may be quoted without explicit permission provided that full credit, including (C) notice, is given to the source. 
Transparency and International Investor Behavior

R. Gaston Gelos and Shang-Jin Wei

NBER Working Paper No. 9260

October 2002

JEL No. F30, D80, G10, G30

\section{$\underline{\text { ABSTRACT }}$}

Does country transparency affect international portfolio investment? We examine this and related questions using some new measures of transparency and a unique micro dataset on international portfolio holdings. We distinguish between government and corporate transparency. There is clear evidence that international funds invest systematically less in less transparent countries. On the other hand, herding among funds tends to be more prevalent in less transparent countries. There is also some evidence that during crises, funds flee non-transparent countries by a greater amount.

R. Gaston Gelos International Monetary Fund

Room 9-718 $70019^{\text {th }}$ Street, N.W.

Washington, DC 20431

ggelos@imf.org

\author{
Shang-Jin Wei \\ International Monetary Fund \\ Room 10-700m \\ 700 19th Street N.W. \\ Washington, DC 20431 \\ and NBER \\ swei@imf.org
}




\section{INTRODUCTION}

In policy circles, lack of transparency has frequently been blamed for the recent financial crises in emerging markets. For example, the IMF (2001) notes that a "lack of transparency was a feature of the buildup to the Mexican crisis of 1994-95 and of the emerging market crises of 1997-98," stating that "inadequate economic data, hidden weaknesses in financial systems, and a lack of clarity about government policies and policy formulation contributed to a loss of confidence that ultimately threatened to undermine global stability." Consequently, the international financial institutions have actively promoted more transparency among their member countries as well as made strides to become more transparent in their own operations.

The strive for more transparency presupposes that destabilizing behavior by individual investors can be avoided or attenuated by improved provision of information. For example, international investment funds may be more likely to engage in herding in less transparent countries (where herding is defined as funds taking investment decisions which they would not take if they did not observe other funds taking them). As a result, investors may rush in and out of countries even in the absence of substantial news about fundamentals.

In theory, however, it is controversial whether lower country transparency yields higher herding or volatility. On the one hand, one set of theoretical explanations of herding behavior relies on asymmetric information (e.g., Bikhchandani et al., 1992; Banerjee, 1992; Devenow and Welch, 1996; Bikhchandani and Sharma, 2000). We would note that there is a natural linkage between low transparency and asymmetry of information. Low transparency typically does not mean that no one knows anything. Rather, lower transparency means that less information is made publicly available, which in turn implies that the gap between those who know and those who do not becomes larger. Such higher informational asymmetry should therefore result in more herding.

On the other hand, herding by institutional investors can be rationalized without an appeal to informational asymmetry at all, but instead by the incentives faced by fund managers that result from the need to have their performances compared periodically with a common benchmark (Scharfstein and Stein, 1990; and Chevalier and Ellison, 1999). In this case, an 
improvement in a country's transparency would not imply a reduction in international investors' herding behavior.

Related to this discussion, the theoretical link between availability of information and market volatility is ambiguous, as pointed out, among others, by Furman and Stiglitz (1998). While their argument is not specifically about herding behavior, it is about investors' trading behavior in different information environments. In particular, they suggest that if more transparency means a higher frequency of information release (holding the true value of the fundamental constant), price volatility could increase rather than decline. The notion that transparency may not necessarily reduce volatility is reflected in the recent literature on corporate transparency. In particular, Bushee and Noe (2000) report a positive association between corporate transparency and the volatility of the firm's stock price. Firms with higher levels of disclosure tend to attract certain types of institutional investors which use aggressive, short-term trading strategies which in turn can raise the volatility of the firm's stock price. It is not clear whether this investor self-selection story can be generalized to international context. Ultimately, the effect of transparency on the behavior of international investors is an empirical question.

International evidence on this question, however, is still lacking. To be sure, there are several empirical studies that measure the degree of herding among funds, including Lakonishok, Shleifer and Vishny (1992), Grinblatt, Titman and Wermers (1995), and Wermers (1999) for the U.S., Choe, Kho and Stulz (1999) and Kim and Wei (2002) for Korea, and Borensztein and Gelos (forthcoming) for emerging markets worldwide. However, as far as we know, there is no paper that studies the connection between a country's level of transparency and the degree of herding by international investors.

Transparency may also affect the level of international portfolio investment in addition to its effect on herding. On this, there is less disagreement in the existing literature. In the corporate finance context, Diamond and Verrechia (1991), among others, have argued that a reduction in informational asymmetry can increase the investment from large investors and hence reduce the cost of capital for the firm (see Healy and Palepu, 2001, and Core, 2001, for reviews of the empirical literature on corporate disclosure). So far, there is no theoretical paper that has modeled explicitly the effect of a country's transparency on the level of international portfolio 
investment ${ }^{2}$. However, it seems reasonable to extrapolate from the corporate finance literature that an improvement in a country's transparency can be expected to lead to an increase in the level of investment by international mutual funds.

We aim to accomplish two main objectives in this paper. First, we investigate the effect of transparency in developing countries on the level of investment by international institutional investors. Second, we examine the effect of transparency on the degree of herding among funds (as well as related issues). Apart from the novelty of the questions examined, two important features of the paper are the construction of transparency measures and the use of a unique micro investment data set containing the country allocation of over 300 emerging market funds at a monthly frequency over 1996-2000. The investment information at the individual fund level allows us to measure herding behavior, which is not possible with aggregate data.

We distinguish between government and corporate transparency. Within the category of government transparency, we further differentiate between macroeconomic data availability (timeliness and frequency) and transparency in the conduct of macroeconomic policies. Corporate transparency refers to availability of financial and other business information about firms in a country on average. It turns out that each measure contains information not captured by the other ones ${ }^{3}$. For example, the correlation between corporate transparency and government data transparency is 0.02 , and the correlation between corporate and government macropolicy transparency is 0.54 .

\footnotetext{
2 There are several somewhat related papers which we cannot survey completely here. Portes and Rey (1999) examine the role of information in explaining cross-border volume of equity flows, though they do not look at any measure of transparency at the country level. Wei (2000) studies the effect of corruption on inward foreign direct investment and bank borrowing, but not the effect of transparency on equity investment by international mutual funds. Using data on U.S. holdings of equities, Griever, and Warnock (2000) examine how informational asymmetries affect the home bias.

${ }^{3}$ Note that we do not focus on corruption, the rule of law, or specific corporate governance aspects, such as the degree of minority shareholder protection in this paper. Rather, we try to capture as accurately as possible the notion of information quality and availability.
} 
The main findings of the paper can be summarized here. First, there is relatively clear evidence that low transparency - or high opacity -- tends to depress the level of international investment. Government opacity and corporate opacity have separate, depressing effects on investment. Second, there is a moderate amount of evidence that low transparency in a developing country leads to an increase in the herding behavior by international investors. Thus, if herding by international investors contributes to a higher volatility or more frequent financial crises in emerging markets, it is not unrelated to the transparency features of the countries. Third, funds seem to react less strongly to news about country fundamentals in less transparent countries. Fourth, there is some evidence that during crises, funds flee non-transparent countries and invest in more transparent ones.

\section{Data}

Two sets of variables are crucial for our analysis. The first is a data set on investment positions by individual international funds in various countries. The second set is related to various measures of transparency. We explain the two sets of data in turn.

\subsection{Data on Emerging Market Funds}

We use data from a comprehensive database purchased from eMergingPortfolio.com (formerly Emerging Market Funds Research, Inc.). The database covers, on a monthly basis, the country asset allocation of hundreds of equity funds, a few of which have a global investment strategy, but most of which have a focus on emerging markets. The period covered is January 1996-December 2000. At the beginning of the sample, the database contains 382 funds with assets totaling US\$117 billion; at the end of 2000, the number of funds covered is 639, managing US\$120 billion. Approximately one quarter of the funds are closed-end funds. The funds are domiciled mostly in advanced economies and offshore banking centers. We exclude singlecountry funds.

In February 1999, the sample consisted of 9 international funds (not focusing on emerging markets), 53 global emerging market funds, 125 Asian regional funds, 52 regional 
Latin American funds, and 39 funds focusing on other geographic areas. Approximately one quarter of the funds are closed-end funds. The assets of these funds represent a modest, but not negligible fraction of the total market capitalization. For example, in the case of Argentina, funds held approximately 6.5 percent of the total stock market capitalization in August of 1998, while the share was around 4.5 percent for Hungary and Korea.

The data set provides asset positions in each country at a given point in time (month end). Since we are mainly interested in the flows to individual countries, we infer their values from the asset position data under some assumptions on changes in the stock valuation. In particular, we assume that in any given country, the funds hold that country's index (or, more precisely, a portfolio of stocks that is well approximated by the IFC investable index. ${ }^{4}$ We assume that flows occur halfway through the period. For investment flow from fund $i$ to country $c$ in month $t$ we assume that:

$$
\text { Flow }_{\text {cit }}=\left[\text { Assets }_{i, c, t}-\text { Assets }_{i, c, t-1}\left(1+\operatorname{Index~}_{\operatorname{return}}\right)\right] /\left(1+\operatorname{Index~return~}_{\mathrm{ct}}\right)^{1 / 2}
$$

This obviously represents an approximation. However, consistency checks for closed-end funds show that our approximation is reasonable. ${ }^{5}$

\subsection{Measuring (Lack of) Transparency}

In this paper, we use the term transparency to denote the availability and quality of information, measured at the country level. In particular, we focus on two categories of opacity: governmental and corporate. Within the category of government opacity, we construct separate measures for opacity in macroeconomic policies and opacity in the availability of macroeconomic information. For corporate opacity, we work with an index of availability and

\footnotetext{
${ }^{4}$ Where the IFC does not compute an investable index, we used the global index. For countries not covered by the IFC, we employed MSCI US dollar index data or national indices converted into U.S. dollars.

${ }^{5}$ The correlation between imputed and actual changes in total assets is 0.93 .
} 
reliability of corporate accounting information. In addition, we use a new composite index of opacity intended to combine information about opacity in accounting, regulation, the legal system, economic policy, and bureaucratic corruption. This index potentially crosses the distinction between government and corporate opacity.

\section{Government Opacity}

On government transparency, we look into two separate aspects. The first concerns the transparency and predictability of a government's macroeconomic policies, and the second concerns the frequency and timeliness of government information release.

We construct a measure of macro policy opacity based on two measures developed by Oxford Analytica for Wilshire Associates. Oxford Analytica produced detailed reports for 27 countries, based on which it assigned scores to fiscal and monetary policy. For about half of the countries, Oxford Analytica relied heavily on the recent "Reports on Standards and Codes" (ROSCs) produced by the IMF. Because the ratings are largely based on the degree to which a government's macro policies conform with the prescribed standards and codes rather than actually realized size of inflation or fiscal deficits, they have, in principle, been filtered by the impact of shocks to an economy. We use the sum of these scores, subtract it from ten, and label this variable MACROPOLICY OPACITY (See Appendix I).

We construct a measure of macro data opacity based on two indices developed by the IMF on the frequency and timeliness of national authorities' macroeconomic data dissemination for all its member countries. The indices are available for 1996, 1997 and 2000 (Allum and Agça, 2001). We subtract these values from ten, construct a simple average of the two variables for each year and call it MACRODATA OPACITY. For the years 1998 and 1999, we use the values from 1997.

\section{Corporate Opacity}

The yearly Global Competitiveness Report produced by the World Economic Forum used to include results from surveys about the level of financial disclosure and availability of information about companies. Based on these results, we construct a summary variable called 
CORPORATE OPACITY (further details are given in Appendix I). This gives us a one-time cross-country measure of average opacity in the corporate sector.

\section{Composite Opacity}

The accountancy and consulting company PriceWaterhouseCoopers conducted a survey of banks, firms, equity analysts, and in-country staff in 2000 to generate measures of opacity in five areas (PriceWaterhouseCoopers, 2001): bureaucratic practices (corruption), legal system, government macroeconomic policies, accounting standards and practices, and regulatory regime. We call this variable OFACTOR.

\section{Correlation Among the Opacity Measures}

A list of countries in our sample and their associated opacity measures are in Table A1. These different measures of opacity indeed appear to capture different aspects of country opacity: the correlation among them is positive but far from perfect (Table 1). The overall measures OFACTOR is strongly correlated with CORPORATE OPACITY (correlation coefficient $=0.69$ ), and the correlations between MACROPOLICY OPACITY and MACRODATA OPACITY is also quite high (0.63). The relationship between CORPORATE OPACITY and OFACTOR on the one hand and the macroeconomic opacity measures on the other hand is low. In order to highlight that the opacity measures measure something different than just economic development, the table also shows the correlation of the opacity indices with GDP per capita. The correlation of OFACTOR and CORPORATE OPACITY with GDP per capita is statistically significant but far from perfect.

\section{EMPIRICAL RESULTS}

\subsection{Transparency ANd Country AsSet Allocation}

In this sub-section, we assess whether funds tend to allocate less money to less transparent countries. To do this, we need a benchmark on how international mutual funds would invest if all countries were equal on the transparency dimension. We take as our guidance the 
International Capital Asset Pricing Model, which predicts that international mutual funds should hold each country's asset in proportion to its share in the world market portfolio. As an empirical proxy for the world market portfolio, we choose the popular MSCI Emerging Markets Free (EMF) Index produced by Morgan Stanley. The index is essentially based on market capitalization of a country's stocks that are available to foreign investors. It is common for asset managers to report their positions relative this index and for investment banks to issue recommendations relative to it (e.g., "over-weight Singapore" means "advisable to invest more than Singapore's weight in the MSCI EMF index"). Indeed, Disyatat and Gelos (2001) report evidence that the country allocation of dedicated emerging market funds can, to a large extent, be explained by the MSCI EMF index.

The empirical strategy in this paper is to examine whether a country's measure of opacity helps to explain mutual funds' investment position after we take into account the country's share in the MSCI EMF index. (We will also add other control variables later on.) To be more precise, we regress the actual country weights on benchmark index weights and measures of transparency. The EMF index includes only investment opportunities available to the international investor. The regressions are of the form:

$$
w_{i, j, t}=\alpha_{j}+\beta \cdot w_{i, t}^{\text {benchmark }}+\gamma \cdot \text { OpacityIndex }{ }_{t}+\varepsilon_{i t}
$$

where $\mathrm{w}_{i, j, t}$ denotes the weight of country $i$ in fund $j$ 's portfolio at the end of period $t$ and $\alpha_{\mathrm{j}}$ is a fund fixed effect. The right-hand side variables do not vary with the fund dimension $\mathrm{j}$. For this reason, we allow for clustering of the errors around the country $\mathrm{j}$ dimension to avoid artificially inflated t-statistics. ${ }^{6}$ The coefficient on OpacityIndex would be negative if emerging markets funds systematically invested less in less transparent countries.

\footnotetext{
${ }^{6}$ See Rogers (1993). A less efficient alternative is to simply form averages by fund and allowing for serial correlation by country, and we obtain very similar results when proceeding this way. A related problem concerns the estimation of the effect of aggregate variables on micro data, since it requires awareness that errors are likely to be correlated within the groups formed by the aggregate variables (see Moulton, 1986). Aggregating by funds obviously solves this problem. Alternatively, we allow for clustering of the errors for each country-month group, and the effect of the transparency variables remains statistically significant.
} 
There are two things worth noting at the outset. First, the total market capitalization in any country must be held in the aggregate by some investors. In other words, not all investors can be "underweight" in less transparent countries. Therefore, our empirical investigation concerns whether and how the level of foreign investment relative to domestic investment is affected by opacity. Second, here we ignore any effect of transparency on a country's share in the MSCI EMF index itself. It seems plausible that less transparency would inhibit the development of a country's financial market, an issue we do not examine in this paper. To the extent that this is true, our estimates may underestimate the true negative effect of opacity on the level of international investment. Note, however, as long as the opacity measure is uncorrelated with the error term in the regressions, its coefficient estimate are still consistent albeit less precise if opacity is correlated with the share in the EMF index.

The regression results are reported in Table 2. Without exception, lack of transparency is associated with lower exposure of emerging market funds. The overall opacity index and all four indices of corruption are statistically significantly and negatively correlated with country weights. ${ }^{7}$ The estimated effect of opacity on international investment is not huge but not trivial either. For example, the estimate using OFACTOR as the opacity measure suggests that a country like Venezuela, currently represented with an average 0.4 percent weight in the sample's portfolios, could achieve a 1.7 average higher percentage weight in fund portfolios if it increased its transparency to Singapore's level. ${ }^{8}$

While we believe that the MSCI EMF index provides a good benchmark for our analysis, other factors might be relevant in determining the country allocation of funds' assets. Therefore, we make an attempt to control for many that might be suspected of being correlated with

\footnotetext{
${ }^{7}$ This finding is similar to that of Ahearne, Griever, and Warnock (2000), who find that an interaction variable of an index measuring rule of law and an index measuring accounting standards contributes to explaining U.S. holdings of foreign equities.

${ }^{8}$ The effect of opacity may depend on market capitalization. We therefore also used percentage deviations from the MSCI benchmark a dependent variable, leaving out the MSCI index as an explanatory variable. This reduces our sample since some countries have zero weight in the MSCI, but the main results are not affected.
} 
opacity. ${ }^{9}$ (1) Funds might prefer to be overweight in more liquid markets, and transparency measures might be proxying for market liquidity. Therefore, we include average turnover (average monthly value traded divided by mean market capitalization) as an additional variable. (2) Fund managers could prefer countries with strong protection of minority shareholders, and transparency might pick up this effect. Therefore, we include the summary variable on minority shareholder rights constructed by La Porta, López de Silanes, Shleifer, and Vishny (1998) and extended by Pistor, Raiser and Gelfer (2000) for transition economies in the regressions. (3) Countries classified by us as less transparent may be countries with closely held stock ownership. Pinkowitz, Stulz, and Williamson (2001) point out that only a fraction of the market capitalization in most countries is available to international investors who are not controlling shareholders. They compute the percentage of firms closely held for many countries, and show that home bias by U.S. investors can largely be explained by this effect. We include their measure of closely held shares in our regressions. (4) One may also suspect that our opacity measures are likely to capture other factors associated with economic development, not necessarily market opacity. For this reason - although there is no clear justification for doing so-we also include GDP per capita as an additional explanatory variable. (5) Opacity indices may be capturing country risks more broadly rather than those specifically associated with lack of transparency. We therefore include monthly summary risk variables for economic, financial, and political risk produced by International Country Risk Guide. ${ }^{10}$ Note that this in some sense represents an "overcorrection," since the political risk measure captures some country characteristics that are related to transparency — in fact these variables have occasionally been used to measure transparency. ${ }^{11} \mathrm{We}$ also include a three-year moving average of mean returns to

\footnotetext{
${ }^{9}$ The MSCI index weights themselves may be a function of opacity: when a market becomes more transparent, it may grow and increase its weight in the index. If this were the case, it would make it harder to find any significant effects of opacity.

${ }^{10}$ For details, see Appendix B. Note that the ICRG variables have been used in the finance literature to derive expected returns. See Erb, Harvey, and Viskanta (1996).

${ }^{11}$ See Furman and Stiglitz (1998).
} 
capture the possibility that fund managers are return chasing. We allow for the effect of opacity to vary between tranquil and crises times. ${ }^{12}$

When including these control variables, all opacity variables continue to have negative and statistically significant coefficients, with their magnitude broadly unchanged (Table 3). Interestingly, during crises, the effect of opacity becomes less important. This possibly reflects panic selling across all emerging markets during a crisis when the distinction among countries in terms of opacity becomes less important. In any case, the negative effect of opacity on international investment (reported in Table 2) is not driven by crisis episodes in the sample. The coefficients on the other control variables mostly have the expected signs and are often statistically significant. An exception is that funds tend to prefer politically risky countries.

Lastly, exchange rate regimes might potentially be correlated with opacity and fund managers may have a preference for certain types of exchange rate arrangements. While the ICRG variables contain a component related to exchange rate variability, in another specification, we therefore explicitly include monthly dummies for five different types of exchange rate regimes based on recent work by Reinhart and Rogoff (2002). Table 4 adds these variables describing the features of a country's exchange rate regime to the list of control variables. We see that each of the opacity variable continues to be negative and statistically significant. Concerning exchange rate regimes, funds appear to have a "fear of floating.",13

A potential problem is that some of our opacity measures were constructed toward the end or even after the sample period. We therefore also use an earlier measure of corporate opacity, namely the accounting standard variable proposed by La Porta, Lopez-de-Silanes, Shleifer, and Vishny (1998). ${ }^{14}$ The measure was published in 1991, and for Indonesia and Pakistan we use values published in 1993 following Doidge, Karolyi and Stulz (2002). We find that the degree of accounting opacity has a significant negative effect on holdings, with

\footnotetext{
${ }^{12}$ We interacted the opacity variable with a crisis dummy, which was set equal to one for the period of the Asian, Russian, and Brazilian crises (97:07-98:01, 98:07-98:09, 99:01).

${ }^{13}$ Calvo and Reinhart (2002) show that governments suffer from a "fear of floating."

${ }^{14}$ To be consistent with our other measures, we subtract the original variable from 100 , so that higher levels denote higher accounting opacity.
} 
coefficients ranging from -0.025 (t-statistic: -4.06$)$ in the simple regression to -0.034 (t-statistic: 3.68 ) in a regression including control variables.

These results are not the artifact of individual outliers. We compare the means of the differences between actual and MSCI index portfolio weights for samples in which the opacity variable was below or above its median (Table 5). The differences in portfolio weights for the two subsamples are in line with the regression results and the hypothesis of equality in means can always be rejected.

\section{A Horse Race Among Different Transparency Dimensions}

What is the relative importance of these dimensions of transparency? To assess this question, we run a simple "horserace" between our measures, including them jointly in regressions (Table 6). We do not include OFACTOR since it is a summary variable encompassing both corporate and macroeconomic transparency. When we do not include control variables except for the benchmark index weights (as in Table 2), the coefficients on each of the three opacity measures retain their approximate size and significance, while the government transparency variables become statistically insignificant. By contrast, when including control variables (as in Table 3), the coefficients become much larger in (absolute) size, with the coefficient on MACRODATA OPACITY turning positive. We therefore tentatively conclude that at least corporate opacity and macropolicy opacity separately contribute to a reduction in international investment.

\subsection{The Effect of Transparency on Investors' Herding Behavior}

Is herding more or less prevalent in less transparent countries? To measure the extent of herding behavior, we compute a statistic of trading co-movement originally introduced by Lakonishok, Shleifer, and Vishny (1992). ${ }^{15}$ The measure allows us to assess whether funds move

\footnotetext{
${ }^{15}$ Borensztein and Gelos (forthcoming) compute and discuss herding among the funds examined here. They find moderate, but statistically significant evidence for herding. The mean of HM across countries and over time is 7.7 percent, about twice as large as the number found for
} 
in the same direction more often than one would expect if they traded independently and randomly. The indicator, denoted HM (for herding measure), is given by:

$$
\mathrm{HM}_{i t}=\left|\mathrm{p}_{i t}-\mathrm{E}\left[\mathrm{p}_{i t}\right]\right|-\mathrm{E}\left|\mathrm{p}_{i t}-\mathrm{E}\left[\mathrm{p}_{i t}\right]\right|
$$

where $\mathrm{p}_{i t}$ is the proportion of all funds active in country $i$ in month $t$ that are buyers:

$$
p_{i t}=\frac{\# \text { ofBuyers }(i, t)}{\# \text { ofBuyers }(i, t)+\# \text { ofSellers }(i, t)} \text {, }
$$

and $\mathrm{E}\left[\mathrm{p}_{i t}\right]$ is its expected value. By taking the absolute value, the first term in equation (3) captures imbalances in both directions, buying or selling.

The expected fraction of buyers $\mathrm{E}\left[\mathrm{p}_{i t}\right]$ may vary over time - for example, there might be periods of large inflows into emerging market funds, during which we would observe most funds buying contemporaneously. We approximate $\mathrm{E}\left[\mathrm{p}_{i t}\right]$ by the total number of net buyers across all countries divided by the total number of active funds in that month:

$$
E\left[p_{i t}\right]=\frac{\sum_{i=1}^{N} \# \operatorname{Buyers}(i, t)}{\sum_{i=1}^{N} \# \operatorname{Buyers}(i, t)+\# \operatorname{Sellers}(i, t)}
$$

Since the distribution of the absolute value of the first expression is not centered around zero, the expected value $\mathrm{E}\left|\mathrm{p}_{i t}-\mathrm{E}\left[\mathrm{p}_{i t}\right]\right|$ needs to be subtracted. Under the null hypothesis of no herding, this expected value is calculated assuming that the number of buyers follows a binomial distribution. It should be pointed out that evidence for correlated trading patterns is a necessary,

domestic U.S. institutional investors. See Kim and Wei (2002a) and Choe, Kho, and Stulz (1999) for evidence of herding among international investors in Korea. 
but not sufficient condition for the existence of herding in a strict sense- the specific class of investors we are examining may react in the same way to news about fundamentals.

We compute averages of $\mathrm{HM}_{i t}$ for each country over the 60 periods. To include only meaningful notions of "herds," we include only observations with at least five active funds. Moreover, in order to limit the impact of approximation errors, we classify a fund as buyer or seller only if the absolute value of the calculated (out-) flow into (or from) a country is larger than three percent of the fund's assets in that country. We then examine correlations between herding and country transparency. To our knowledge, this is among the first attempts to relate the degree of herding to country characteristics rather than investors.

While herding is somewhat higher in less transparent countries, the relationship is weak. Mean herding values are higher for more opaque countries, although the difference is only significant at the 5 percent level for OFACTOR and at the 10 percent confidence level in the case of MACROPOLICY OPACITY and CORPORATE OPACITY (Table 7). Figure 2 shows the simple, unconditional relation between HM and OFACTOR. There is an apparent positive association between a country's opacity and the tendency for international investors to herd when investing in this country's assets.

The results are similar when including control variables. We regress these herding averages on our country transparency indices, average turnover and average market capitalization (Table 9). ${ }^{16}$ Mean turnover (defined as the country average of monthly value traded divided by market capitalization) should proxy for market liquidity. Herding strategies are likely to be easier to implement in more liquid markets, where the price impact of any trade is lower. Concerning market size, Borensztein and Gelos (forthcoming) report that herding is more pronounced in larger markets, and we therefore include size as a control variable in these simple regressions. The coefficients on two transparency measures, namely OFACTOR, and CORPORATE OPACITY are significant at the five percent level. In some cases, the included variables explain a substantial fraction of the variation of herding across countries (the $\mathrm{R}^{2 \text {, }} \mathrm{s}$ range from 0.01 to 0.3 ). When including GDP per capita as an additional regressor, only

\footnotetext{
${ }^{16}$ Wherever we have time variation in the transparency levels, such as in the case of MACRODATA OPACITY, we use simple averages of the variables.
} 
OFACTOR remains significant at the five percent level (CORPORATE OPACITY is still significant at the 10 percent level).

We again carried out a horserace between transparency measures (not shown): since the number of observations shrinks to 23 while the number of explanatory variables increases, the estimates loose precision and none of the transparency indices remains significant at the 5 percent level.

Similarly to our finding on investment levels, the relationship between the degree of herding and opacity appears to be weaker during crises. We computed the herding measure for only the crisis months mentioned earlier. In the regressions, none of the opacity variables was significant at the five percent level (not reported to save space).

\subsection{The Reaction to News}

An issue closely related to herding is the reaction of investors to news. Timely and comprehensive data dissemination by national authorities are intended to avoid situations in which any piece of bad news — whether accurate or not — is potentially seen by market participants as the tip of a hidden iceberg, with ensuing panicky reactions which be quickly magnified by herding behavior.

Furman and Stiglitz (1998) argue that the mean of investors' expectations is unlikely to be affected by a lack of transparency. However, the variance of expectations across investors is likely to be higher and their prior beliefs flatter. Any information received might therefore have a larger effect on investors' beliefs.

On the other hand, news about more transparent countries will on average convey more useful information than news about opaque countries, so that markets may react more strongly to news in transparent markets. Put differently, if one thinks of signals (news) as composed of a "fundamental" plus an error term (whose variance is a function of transparency), the reaction to news should be lower the higher the variance of the error term. Core (2001) and Shu (2000) make this point in the context of corporate disclosure. This view is consistent with the notion that in transparent markets, investment decisions are largely driven by the reaction to news about fundamentals rather than by herding behavior. 
In order to assess whether funds react differently to news depending on the degree of country opacity, we relate changes in country portfolio weights to revisions in Consensus GDP forecasts (CONSNEWS). ${ }^{17}$ First, we regress changes in portfolio weights on CONSNEWS and an interaction variable of CONSNEWS multiplied with the various transparency variables to assess the differential effect of opacity. ${ }^{18}$ Then, again we include control variables to assess the robustness of our results. The regressions are of the form:

$$
\begin{aligned}
& \Delta w_{i, j, t}=\alpha \cdot \text { CONSNEWS } \\
& \gamma \cdot \text { Controlvar } \cdot \text { CONSNEWS } \\
& \gamma \cdot \text { Opacity Index }_{i, t}+\eta_{j}+v_{i}+\varepsilon_{i, j, t}
\end{aligned}
$$

where $\Delta \mathrm{w}_{i, j, t}$ denotes the change of weight of country $i$ in fund $j$ 's portfolio at the end of period $t$, $\eta_{j}$ and $v_{i}$ are fund and country fixed effects, and $\varepsilon_{i j t}$ is an error term.

After controlling for other country variables, including risk factors, the results show that the reaction to news is more muted in more opaque countries (Table 9). The only exception is the effect of CORPORATE OPACITY. The results also indicate that funds react more strongly about news in larger and more liquid markets, since the interaction terms with market capitalization and turnover are significantly positive. The results are robust to the inclusion of country random effects.

These result suggest that the signal-to-noise ratio regarding macroeconomic fundamentals is indeed lower in more opaque countries. Accordingly, after the release of positive macroeconomic news, fund managers may want to wait for further confirmation before engaging in a costly reallocation of assets across countries.

\footnotetext{
${ }^{17}$ The surveys are published at the end of month in which they are conducted. We use a weighted average of current-year and year-ahead forecasts: in February, the current-year forecast is given a weight of 5/6, and next year's forecast a weight of $1 / 6$, and so forth. We call the bimonthly difference between these forecasts CONSNEWS.

${ }^{18}$ Note that we do not include the opacity variable as a separate regressor, since opacity levels should not have an effect on changes in country weights.
} 


\subsection{Flows during crises}

While the overall relationship between herding and opacity is of interest, a more specific question concerns the extent to which difference in opacity helps to explains which countries are more likely to be hit by outflows during crises. Are more opaque countries more prone to contagion effects? Do transparency measures, beyond and above macroeconomic indicators, explain the degree of confidence loss across countries during turbulent times?

Johnson and others (2000) have examined whether measures of corporate governance, in particular the effectiveness of minority shareholder protection, help explain the extent of currency depreciation and stock market decline across countries during the Asian crisis. They find that corporate governance variables can account for a larger fraction of the variation in performance than standard macroeconomic variables. The fact that their regressions contain only 25 observations, however, limits inference. For example, when including GDP per capita, the coefficients on corporate governance variables become insignificant. It is therefore not clear whether other country characteristics correlated with economic development, such as transparency as defined here, is driving the results.

We relate the size of monthly fund flows during the Asian and Russian crises to our measures of country transparency. Specifically, we look at flows relative to preceding month's holdings of individual funds across countries during the period of the Asian and Russian crises, namely May 1997-September 1998. [We have also examined the Asian and Russian crises separately, and found that the main conclusions are not sensitive to the choice of horizons.] The regression equation therefore had the form:

$$
\frac{f_{i j t}}{A_{i j t-1}}=\alpha \cdot \text { OpacityIndex }+\beta \cdot \text { ControlVar }+\eta_{j}+v_{i}+\varepsilon_{i, j, t}
$$

Where $f_{i j t}$ is the flow of fund $j$ into country $i$ at time t, $A_{i j t-1}$ are the assets of fund $j$ in country $\mathrm{i}$ at time $t-1, \eta_{j}$ is a fund fixed effect and $v_{i}$ a country random effect. A negative value of $\alpha$ indicates that capital outflows are greater in less transparent countries.

The basic results are reported in Table 11. The coefficients on all measures of opacity consistently have a negative sign. This suggests that more opaque countries indeed experience 
larger outflows during the crises (though the coefficient is not significant for the composite Ofactor measure). In Table 12, we observe that the link between outflow and opacity is still visible when controlling for other variables. In particular, the coefficients on MACROPOLICY OPACITY and MACRODATA OPACITY are significant at the five percent level. In a horserace between the three opacity indices, MACROPOLICY, MACRODATA, and CORPORATE OPACITY, reported in Table 13, only MACRODATA OPACITY enters significantly at the five percent level.

Note that the estimation technique used here is relatively conservative, since in addition to fund fixed effects, we include country random effects, which can be expected to absorb a significant fraction of the variation in country characteristics. Instead of the ICRG risk measures, we also used crisis probabilities as predicted by the early warning model of Berg and Pattillo (1999) and Kaminsky, Lizondo, and Reinhart (1998) as controls, without changing the main results (not shown to conserve space).

As a robustness check, we also employ a measure of accounting standard quality proposed by La Porta, López-de-Silanes, Shleifer, and Vishny (1998) (LLSV). The measure was published in 1991 and hence pre-determined relative to the investment positions of the funds in our sample. It turns out that the results using this variable are very similar to the ones obtained with CORPORATE OPACITY.

\section{Conclusion}

This paper represents a first assessment of the impact of country transparency on the behavior of international investment funds. There are a few noteworthy findings. First, we find relatively clear evidence that international funds prefer to hold more assets in more transparent markets. Second, on the other hand, herding among funds is more prevalent in less transparent countries. Third, there is some modest evidence that during a crisis, international investors tend to flee more opaque markets.

We conjecture that the effects of opacity documented here are likely to represent a lower bound for the overall effects on the universe of international investors that go beyond specialized emerging market funds. In future research, it would be useful to contrast these findings with the 
behavior of other players in international capital markets, and with that of domestic investors in these countries. 


\section{Transparency Variables}

\section{Measures of Government Transparency}

\section{Transparency of Macroeconomic Policies}

Here, we rely on two measures developed by Oxford Analytica for Wilshire Associates. Wilshire Associates (2002) had in turn commissioned this work as part of an investment analysis on "permissible equity markets" produced for the California Public Employees' Retirement System. Oxford Analytica delivered detailed reports for 27 countries, on which basis it assigned a score from 1 (least transparent) to 5 (most transparent) to fiscal and monetary policy. The reports were to a significant extent based on the IMF's recent Reports on Standards and Codes (ROSCs) - the IMF, however, did not assign scores to individual countries. We use the sum of Oxford Analytica's scores, which ranges from three to eight, and subtract it from ten and label the variable MACROPOLICY OPACITY.

\section{Frequency and Timeliness of Macroeconomic Data Dissemination}

The IMF has computed indices of the frequency and timeliness of national authorities' macroeconomic data dissemination for all its member countries. The indices are available for 1996, 1997 and 2000 (see Allum and Agça, 2001). We use the average of these three values and subtract them from ten. Then, we construct a simple average of the two variables and call it MACRODATA OPACITY. For 1998 and 1999 we use the 1997 values.

\section{Corporate Transparency}

The Global Competitiveness Report includes results from surveys about the level of financial disclosure. The respondents have to assess the validity of the statement "The level of financial disclosure required is extensive and detailed" with a score from 1 (=strongly disagree) to 7 (strongly agree). We use the numbers appearing in the 2000 and 1999 issues (the questions were not covered in other issues), which are based surveys carried out one year earlier. We form a variable FINDIS by subtracting the original variable from eight. Similarly, the Global Competitiveness Report surveys the degree of "availability of information" about business. Again, we use the numbers appearing in the 2000 and 1999 issues, and form a variable AVAIL by subtracting the original variable ranges from eight. We construct a new summary variable, which is equal to the simple average of AVAIL and FINDIS, called CORPORATE OPACITY.

\section{Composite Index}

The accountancy and consulting company PricewaterhouseCoopers has recently conducted a survey of banks, firms, equity analysts, and in-country staff during the third and fourth quarters of the year 2000 to generate measures of opacity in five areas (PricewaterhosueCoopers, 2001): bureaucratic practices (corruption), legal system, government macroeconomic policies, accounting standards and practices, and regulatory regime. This variable is called OFACTOR. 


\section{Data from International Country Risk Guide (ICRG)}

The International Country Risk Guide (ICRG) provides monthly values for 22 components grouped into three major categories of risk: political, financial, and economic, with political risk comprising 12 components, financial risk 5 components, and economic risk 5 components. Each component is assigned a maximum numerical value (risk points), with the highest number of points indicating the lowest potential risk for that component and the lowest number (0) indicating the highest potential risk. The maximum points able to be awarded to any particular risk component is pre-set within the system and depends on the importance (weighting) of that component to the overall risk of a country.

The ICRG staff collects political, economic and financial information, and converts these into risk points for each individual risk component. The political risk assessments are made on the basis of subjective analysis of the available information, while the financial and economic risk assessments are made solely on the basis of objective data.

The components, which are added to construct a risk rating for each subcategory, are listed below. For further details, see http://www.prsgroup.com/commonhtml/methods.html\#_International_Country_Risk.

\begin{tabular}{|c|c|c|}
\hline $\begin{array}{l}\text { Political Risk Components } \\
\text { Government Stability } \\
\text { Socioeconomic Conditions } \\
\text { Investment Profile } \\
\text { Internal Conflict } \\
\text { External Conflict } \\
\text { Corruption } \\
\text { Military in Politics } \\
\text { Religious Tensions } \\
\text { Law and Order } \\
\text { Ethnic Tensions } \\
\text { Democratic Accountability } \\
\text { Bureaucracy Quality }\end{array}$ & $\begin{array}{l}\text { Financial Risk Components } \\
\text { Foreign Debt as a Percentage } \\
\text { of GDP } \\
\text { Foreign Debt Service as a } \\
\text { Percentage of XGS } \\
\text { Current Account as a } \\
\text { Percentage of XGS } \\
\text { Net Liquidity as Months of } \\
\text { Import Cover } \\
\text { Exchange Rate Stability }\end{array}$ & $\begin{array}{l}\text { Economic Risk } \\
\text { Components } \\
\text { GDP per Head of Population } \\
\text { Real Annual GDP Growth } \\
\text { Annual Inflation Rate } \\
\text { Budget Balance as a } \\
\text { Percentage of GDP } \\
\text { Current Account Balance as } \\
\text { a Percentage of GDP }\end{array}$ \\
\hline
\end{tabular}




\section{REFERENCES}

Ahearne, Alan G, William L. Griever, and Francis R. Warnock, 2000, "Information Costs and Home Bias: An Analysis of U.S. Holdings of Foreign Equities," International Finance Discussion Paper 691, Board of Governors of the Federal Reserve System

Allum, Peter, and Mehmet Agça, 2001, "Economic Data Dissemination: What Influences Country Performance On Frequency and Timeliness?," IMF Working Paper 01/173 (Washington: International Monetary Fund).

Banerjee, A., 1992, “A Simple Model of Herd Behavior,” Quarterly Journal of Economics 107, 797-817.

Berg, Andrew and Catherine Pattillo, 1999, “Are Currency Crises Predictable? A Test," IMF Staff Papers, Vol. 46 (June), pp. 107-38.

Bikhchandani, S., Hirshleifer, D., Welch, I., 1992, “A Theory of Fads, Fashion, Custom, and Cultural Change as Information Cascades,” Journal of Political Economy 100, 992-1020.

Bikhchandani, Sushil and Sunil Sharma, 2000, "Herd Behavior in Financial Markets," IMF Staff Papers Vol. 47 (September), pp. 279-310.

Borensztein, Eduardo and R. Gaston Gelos, forthcoming, "A Panic-Prone Pack? The Behavior of Emerging Market Mutual Funds," IMF Staff Papers

Bushee, Brian J., and Christopher F. Noe, 2001, "Corporate Disclosure Practices, Institutional Investors, and Stock Return Volatility," Journal of Accounting Research, Vol. 38 Supplement 2000.

Calvo, Guillermo and Carmen Reinhart, 2002, "Fear of Floating," Quarterly Journal of Economics, Vol. 117 (May), pp. 379-408.

Chevalier, Judith; Ellison, Glenn, 1999, “Career Concerns of Mutual Fund Managers,” Quarterly Journal of Economics Vol.114 (May), pp.389-432

Choe, Hyuk, Bong-Chan Kho, and René Stulz, 1999, "Do Foreign Investors Destabilize Stock Markets?” Journal of Financial Economics, Vol. 54 (October), pp. 227-64.

Chui, Andy C.W., Sheridan Titman, and K.C. John Wei, 2000, "Momentum, Legal Systems and Ownership Structure: An Analysis of Asian Stock Markets" (unpublished manuscript).

Core, John E., 2001, “A Review of the Empirical Disclosure Literature: Discussion,” Journal of Accounting and Economics, Vol. 31, pp. 441-456.

De Long, J.B., Shleifer, A., Summers, L.H., Waldmann, R.J, 1990, "Noise Trader Risk in Financial Markets," Journal of Political Economy 98 (August), pp. 703-738. 
Demirgürç-Kunt, Asli and Enrica Detragiache, 1998, "The Determinants of Banking Crises in Developing and Developed Countries," IMF Staff Papers 45 (March), pp. 81-109.

Diamond, Douglas W. and Robert E. Verrecchia, 1991, "Disclosure, Liquidity, and the Cost of Capital, “ Journal of Finance Vol. XLVI (September), pp. 1325-59.

Disyatat, Piti and R. Gaston Gelos, 2001, "The Asset Allocation of Emerging Market Mutual Funds," IMF Working Paper 01/111 (Washington: International Monetary Fund)

Doidge, Craid, G. Andrew Karolyi, and René Stulz, 2002, "Why are Foreign Firms Listed in the U.S. Worth More?," mimeo

Erb, Claude .B., Campbell R. Harvey, and Tadas E. Viskanta, 1996, "Expected Returns and Volatility in 135 Countries," Journal of Portfolio Management, Vol. 22 (Spring), pp. 4658.

Fisman, Raymond, 2000, "Estimating the Value of Political Connections," American Economic Review, Vol. 91 (September), pp. 1095-1102.

Furman, Jason, and Joseph Stiglitz, 1998, "Economic Crises: Evidence and Insights from East Asia," Brookings Papers on Economic Activity, No. 2, pp. 1-135.

Ghosh, Swati R. and Atish R Ghosh (2002), "Structural Volatility and Currency Crises," IMF Working Paper 02/9 (Washington: International Monetary Fund)

Grinblatt, Mark, Sheridan Titman, and Russ Wermers, 1995, "Momentum Investment Strategies, Portfolio Performance, and Herding: A Study of Mutual Fund Behavior," American Economic Review 85 (December), pp. 1088-1105.

G-22, 1998, Report of the Working Group on Transparency and Accountability

Healy, Paul M. and Krishna G. Palepu, 2001, "A Review of the Empirical Disclosure Literature," Journal of Accounting and Economics, Vol. 31 (September), pp. 441-45.

Institute of International Finance, 1999, Report of the Working Group on Transparency in Emerging Markets Finance," Washington, D.C.

International Country Risk Guide, various years

International Monetary Fund, 2001, IMF Survey Supplement, Vol. 30, September, Washington, D.C., pp. 7-8.

Johnson, Simon, Peter Boone, Alasdair Breach, and Eric Friedman, 2000, "Corporate Governance in the Asian Financial Crisis," Journal of Financial Economics, No. 58 (OctNov), pp. 141-186. 
Kaminsky, Graciela, Saúl Lizondo, and Carmen M. Reinhart, 1998, "Leading Indicators of Currency Crises, “ IMF Staff Papers, 45 (March), pp. 1-48.

Kaminsky, Graciela, Richard Lyons, and Sergio Schmukler (2000), "Managers, Investors, and Crises: Mutual Fund Strategies in Emerging Markets," World Bank Working Paper 2399 (Washington: World Bank)

Kim, Woochan and Shang-Jin Wei, 2002a, "Foreign Portfolio Investors Before and During a Crisis" Journal of International Economics, Vol. 56 (January), pp. 77-96

Kim, Woochan and Shang-Jin Wei, 2002b, "Offshore Investment Funds: Monsters in Emerging Markets?," Journal of Development Economics, Vol. 68 (June), pp. 205-224.

Lakonishok, Josef, Andrei Shleifer, and Robert W. Vishny, 1992, "The Impact of Institutional Trading on Stock Prices," Journal of Financial Economics 32, pp. 23-44

La Porta, Rafael, Florencio López-de-Silanes, Andrei Shleifer, and Robert Vishny, 1998, "Law and Finance," Journal of Political Economy, 106 (December), pp.1113-55.

Mehrez, Gil and Daniel Kaufmann, 2000, “Transparency, Liberalization, and Banking Crises," World Bank Working Paper 2286 (Washington: World Bank)

Morck, Randall, Bernard Yeung, and Wayne Yu, 2000, “The Information Content of Stock Markets: Why Do Emerging Markets Have Synchronours Stock Price Movements?," Journal of Financial Economics, 58 (Oct-Nov), pp. 215-260.

Moulton, Brent R., 1990, “An Illustration of A Pitfall in Estimating the Effects of Aggregate Variables of Micro Units," Review of Economics and Statistics pp. 334-338

Pinkowitz, Lee, René Stulz, and Rohan Williamson, 2001, "Corporate Governance and The Home Bias," mimeo

Pistor, Katharina, Martin Raiser and Stanislaw Gelfer, 2000, "Law and Finance in Transition Economies," Economics of Transition, Vol. 8 (20), pp. 325-68

Portes, Richard and Helène Rey, 1999, "The Determinants of Cross-Border Equity Flows," NBER Working Paper 7336

PricewaterhouseCoopers, 2001, The Opacity Index, www.opacityindex.com.

Reinhart, Carmen and Kenneth S. Rogoff, 2002, "The Modern History of Exchange Rate Arrangements: A Reinterpretation,” NBER Working Paper No. 8963

Rogers, William, 1993, "Regression Standard Errors in Clustered Samples," Stata Technical Bulletin 13 (May), pp. 19-23. 
Scharfstein, D.S. and J.C. Stein, 1990, "Herd Behavior and Investment," American Economic Review 80, pp.465-79.

Shu, Susan, 2000, "Firms' Discretionary Choices in the Face of an Earnings Disappointment," unpublished manuscript, Boston College.

Vishwanath, Tara and Daniel Kaufmann, 2001, "Toward Transparency: New Approaches and Their Application to Financial Markets," The World Bank Research Observer, Vol. 16 (Spring), pp. 41-57.

Wei, Shang-Jin, 2000, "Local Corruption and Global Capital Flows," Brookings Papers on Economic Activity, No: 2, pp. 303-54.

Wei, Shang-Jin, 2001, "Domestic Crony Capitalism and International Fickle Capital: Is There a Connection?," International Finance, Vol. 4 (Spring), pp. 15-45.

Wilshire Associates, 2002, "Permissible Equity Markets Investment Analysis and Recommendations," prepared for The California Public Employees' Retirement System

World Economic Forum, various years, The Global Competitiveness Report, Geneva. 
Table 1. Correlation Between Opacity Measures

\begin{tabular}{|c|c|c|c|c|c|}
\hline & & OFACTOR & $\begin{array}{l}\text { MACROPOLICY } \\
\text { OPACITY }\end{array}$ & $\begin{array}{c}\text { MACRODATA } \\
\text { OPACITY }\end{array}$ & $\begin{array}{l}\text { CORPORATE } \\
\text { OPACITY }\end{array}$ \\
\hline Overall & OFACTOR & 1 & & & \\
\hline \multirow{2}{*}{$\begin{array}{l}\text { Government } \\
\text { Opacity }\end{array}$} & $\begin{array}{c}\text { MACROPOLICY } \\
\text { OPACITY }\end{array}$ & 0.44 & 1 & & \\
\hline & $\begin{array}{l}\text { MACRODATA } \\
\text { OPACITY }\end{array}$ & 0.06 & 0.63 & 1 & \\
\hline $\begin{array}{l}\text { Corporate } \\
\text { Opacity }\end{array}$ & $\begin{array}{l}\text { CORPORATE } \\
\text { OPACITY }\end{array}$ & 0.69 & 0.54 & 0.02 & 1 \\
\hline $\begin{array}{l}\text { Correlation } \\
\text { with income } \\
\text { levels }\end{array}$ & GDP per capita & -0.54 & -0.40 & -0.03 & -0.56 \\
\hline
\end{tabular}

Table 2. The Effect of Opacity on Investment by Global Funds

\begin{tabular}{|l|c|c|c|c|}
\hline & $\begin{array}{c}\text { O-Factor } \\
\text { (Composite) }\end{array}$ & $\begin{array}{c}\text { MACROPOLICY } \\
\text { OPACITY }\end{array}$ & $\begin{array}{c}\text { MACRODATA } \\
\text { OPACITY }\end{array}$ & $\begin{array}{c}\text { CORPORATE } \\
\text { OPACITY }\end{array}$ \\
\hline MSCI Index & $\begin{array}{c}\mathbf{0 . 8 3 9} \\
\mathbf{( 3 6 . 9 0 )}\end{array}$ & $\begin{array}{c}\mathbf{0 . 9 3 3} \\
\mathbf{4 7 . 1 3 )}\end{array}$ & $\begin{array}{c}\mathbf{0 . 8 2 9} \\
\mathbf{( 3 7 . 1 1 )}\end{array}$ & $\begin{array}{c}\mathbf{0 . 8 0 6} \\
\mathbf{( 3 5 . 4 6 )}\end{array}$ \\
\hline Opacity index & $\begin{array}{c}\mathbf{- 0 . 0 8 6} \\
\mathbf{( - 7 . 1 3 )}\end{array}$ & $\begin{array}{c}\mathbf{- 0 . 4 4 9} \\
\mathbf{( - 9 . 2 8 )}\end{array}$ & $\begin{array}{c}\mathbf{- 0 . 3 7 1} \\
\mathbf{- 2 . 3 8 )}\end{array}$ & $\begin{array}{c}\mathbf{- 0 . 9 7 6} \\
\mathbf{( - 9 . 7 4 )}\end{array}$ \\
\hline Number of obs. & 29,621 & 24,944 & 31,180 & 31,180 \\
\hline $\begin{array}{l}\text { Fund fixed } \\
\text { effects }\end{array}$ & Yes & yes & yes & yes \\
\hline $\begin{array}{l}\text { Clustering by } \\
\text { country-month }\end{array}$ & Yes & yes & yes & yes \\
\hline Adj. $\mathrm{R}^{2}$ & 0.66 & 0.66 & 0.63 & 0.62 \\
\hline
\end{tabular}

Dependent variable: $\mathrm{w}_{\mathrm{ijt}}$. T-statistics in parentheses (based on robust standard errors, allowing for clustering by country-month). Regressions include fund fixed effects. Total number of countries: 19-21. 
Table 3. Opacity and Investment by Global Funds: Adding Control Variables

\begin{tabular}{|c|c|c|c|c|}
\hline & OFACTOR & $\begin{array}{l}\text { MACROPOLICY } \\
\text { OPACITY }\end{array}$ & $\begin{array}{l}\text { MACRODATA } \\
\text { OPACITY }\end{array}$ & $\begin{array}{l}\text { CORPORATE } \\
\text { OPACITY }\end{array}$ \\
\hline MSCI Index & $\begin{array}{c}0.861 \\
(43.79)\end{array}$ & $\begin{array}{c}0.794 \\
(24.27)\end{array}$ & $\begin{array}{c}0.840 \\
(31.08)\end{array}$ & $\begin{array}{c}0.818 \\
(30.79)\end{array}$ \\
\hline Opacity Index & $\begin{array}{l}-0.156 \\
(-8.62)\end{array}$ & $\begin{array}{l}-\mathbf{- 0 . 7 3 3} \\
(-8.35)\end{array}$ & $\begin{array}{l}-0.508 \\
(-4.74)\end{array}$ & $\begin{array}{l}-1.428 \\
(-5.42)\end{array}$ \\
\hline $\begin{array}{l}\text { Opacity Index } \cdot \text { Crisis } \\
\text { dummy }\end{array}$ & $\begin{array}{l}\mathbf{0 . 0 0 9} \\
(6.60)\end{array}$ & $\begin{array}{l}\mathbf{0 . 0 8 7} \\
(4.17)\end{array}$ & $\begin{array}{l}0.215 \\
(2.86)\end{array}$ & $\begin{array}{l}0.082 \\
(4.43)\end{array}$ \\
\hline GDP per capita & $\begin{array}{l}\mathbf{0 . 0 9 9} \\
(7.18)\end{array}$ & $\begin{array}{l}\mathbf{0 . 0 7 4} \\
(2.47)\end{array}$ & $\begin{array}{c}0.205 \\
(12.85)\end{array}$ & $\begin{array}{l}\mathbf{0 . 0 7 9} \\
(2.98)\end{array}$ \\
\hline Mean Turnover & $\begin{array}{l}-5.177 \\
(-6.09)\end{array}$ & $\begin{array}{l}1.168 \\
(1.12)\end{array}$ & $\begin{array}{l}-1.756 \\
(-2.54)\end{array}$ & $\begin{array}{l}-7.145 \\
(4.65)\end{array}$ \\
\hline Share of firms closely held & $\begin{array}{l}-0.027 \\
(-5.51) \\
\end{array}$ & $\begin{array}{l}\mathbf{0 . 0 0 6} \\
(0.66) \\
\end{array}$ & $\begin{array}{l}-0.065 \\
(9.78) \\
\end{array}$ & $\begin{array}{l}-0.039 \\
(-5.99) \\
\end{array}$ \\
\hline $\begin{array}{l}\text { Minority Shareholders' } \\
\text { Rights }\end{array}$ & $\begin{array}{l}-0.208 \\
(-4.12)\end{array}$ & $\begin{array}{l}-0.379 \\
(-6.95)\end{array}$ & $\begin{array}{l}-0.092 \\
(-1.88)\end{array}$ & $\begin{array}{l}-0.359 \\
(-4.80)\end{array}$ \\
\hline ICRG Economic Risk & $\begin{array}{r}-0.042 \\
(-2.73) \\
\end{array}$ & $\begin{array}{l}-0.033 \\
(-2.15) \\
\end{array}$ & $\begin{array}{l}-0.042 \\
(-2.89) \\
\end{array}$ & $\begin{array}{l}-0.061 \\
(-3.57) \\
\end{array}$ \\
\hline ICRG Financial Risk & $\begin{array}{l}-0.013 \\
(-0.88)\end{array}$ & $\begin{array}{l}0.014 \\
(1.00)\end{array}$ & $\begin{array}{l}-0.051 \\
(-3.02)\end{array}$ & $\begin{array}{l}0.007 \\
(0.48)\end{array}$ \\
\hline ICRG Political Risk & $\begin{array}{c}-0.119 \\
(-14.79) \\
\end{array}$ & $\begin{array}{l}-0.068 \\
(-7.63) \\
\end{array}$ & $\begin{array}{c}-0.106 \\
(-12.83)\end{array}$ & $\begin{array}{l}-0.084 \\
(-8.79)\end{array}$ \\
\hline Historical returns & $\begin{array}{r}20.857 \\
(6.49) \\
\end{array}$ & $\begin{array}{r}22.873 \\
(5.18) \\
\end{array}$ & $\begin{array}{l}16.419 \\
(4.48) \\
\end{array}$ & $\begin{array}{l}8.925 \\
(2.48) \\
\end{array}$ \\
\hline Number of obs. & 25,255 & 21,672 & 25,379 & 25,844 \\
\hline Fund fixed effects & Yes & Yes & Yes & Yes \\
\hline Adj. $R^{2}$ & 0.66 & 0.66 & 0.63 & 0.60 \\
\hline
\end{tabular}

Dependent variable: $\mathrm{w}_{\mathrm{ijt}}$. T-statistics in parentheses (based on robust standard errors, allowing for error clustering by countries). Regressions include fund fixed effects. Total number of countries: 16. 
Table 4. Opacity and Investment by Global Funds: Adding Exchange Rate Regimes

\begin{tabular}{|c|c|c|c|c|}
\hline & OFACTOR & $\begin{array}{l}\text { MACROPOLICY } \\
\text { OPACITY }\end{array}$ & $\begin{array}{l}\text { MACRODATA } \\
\text { OPACITY }\end{array}$ & $\begin{array}{l}\text { CORPORATE } \\
\text { OPACITY }\end{array}$ \\
\hline MSCI Index & $\begin{array}{c}1.041 \\
(47.56)\end{array}$ & $\begin{array}{c}0.861 \\
(23.62)\end{array}$ & $\begin{array}{c}\mathbf{0 . 8 8 8} \\
(\mathbf{3 3 . 2 3})\end{array}$ & $\begin{array}{c}0.861 \\
(35.28)\end{array}$ \\
\hline $\begin{array}{l}\text { Opacity } \\
\text { index }\end{array}$ & $\begin{array}{l}-0.034 \\
(-1.44)\end{array}$ & $\begin{array}{l}-0.602 \\
(-4.87) \\
\end{array}$ & $\begin{array}{l}-0.494 \\
(-4.59) \\
\end{array}$ & $\begin{array}{l}-2.197 \\
(-8.93) \\
\end{array}$ \\
\hline $\begin{array}{l}\text { Opacity } \\
\text { Index } \cdot \text { Crisis dummy }\end{array}$ & $\begin{array}{l}0.011 \\
(6.03)\end{array}$ & $\begin{array}{l}0.151 \\
(6.92)\end{array}$ & $\begin{array}{l}0.295 \\
(3.85)\end{array}$ & $\begin{array}{l}0.111 \\
(6.11)\end{array}$ \\
\hline GDP per capita & $\begin{array}{c}0.194 \\
(12.55)\end{array}$ & $\begin{array}{l}0.184 \\
(3.86)\end{array}$ & $\begin{array}{c}0.198 \\
(12.29) \\
\end{array}$ & $\begin{array}{l}\mathbf{0 . 0 2 9} \\
(1.10)\end{array}$ \\
\hline Mean Turnover & $\begin{array}{c}-7.829 \\
(-10.39)\end{array}$ & $\begin{array}{l}0.973 \\
(1.27)\end{array}$ & $\begin{array}{l}-5.615 \\
(-7.67)\end{array}$ & $\begin{array}{l}-9.046 \\
(-5.86)\end{array}$ \\
\hline $\begin{array}{l}\text { Minority Shareholders' } \\
\text { Rights }\end{array}$ & $\begin{array}{l}0.041 \\
(0.68) \\
\end{array}$ & $\begin{array}{l}-0.174 \\
(-2.20) \\
\end{array}$ & $\begin{array}{l}0.119 \\
(2.39) \\
\end{array}$ & $\begin{array}{l}-0.306 \\
(-4.07) \\
\end{array}$ \\
\hline Share of firms closely held & $\begin{array}{l}-0.018 \\
(-4.25)\end{array}$ & $\begin{array}{l}0.006 \\
(0.67)\end{array}$ & $\begin{array}{l}-0.049 \\
(-7.85)\end{array}$ & $\begin{array}{l}-0.019 \\
(-3.15)\end{array}$ \\
\hline $\begin{array}{l}\text { Exchange rate } \\
\text { Dummy: peg }\end{array}$ & $\begin{array}{l}-0.181 \\
(-0.29)\end{array}$ & $\begin{array}{l}0.433 \\
(0.68)\end{array}$ & $\begin{array}{l}0.557 \\
(0.82)\end{array}$ & $\begin{array}{l}0.592 \\
(0.89)\end{array}$ \\
\hline $\begin{array}{l}\text { Exchange rate } \\
\text { Dummy: } \\
\text { Limited Flexibility }\end{array}$ & $\begin{array}{l}-0.403 \\
(-0.73)\end{array}$ & $\begin{array}{l}0.905 \\
(1.52)\end{array}$ & $\begin{array}{l}0.258 \\
(0.41)\end{array}$ & $\begin{array}{l}0.355 \\
(0.58)\end{array}$ \\
\hline $\begin{array}{l}\text { Exchange rate } \\
\text { Dummy: } \\
\text { Managed Floating }\end{array}$ & $\begin{array}{l}-0.021 \\
(-0.03)\end{array}$ & $\begin{array}{l}1.805 \\
(2.41)\end{array}$ & $\begin{array}{l}0.837 \\
(1.15)\end{array}$ & $\begin{array}{l}0.603 \\
(0.85)\end{array}$ \\
\hline $\begin{array}{l}\text { Exchange rate } \\
\text { Dummy: } \\
\text { Freely Floating } \\
\end{array}$ & $\begin{array}{c}-3.22 \\
(-4.77)\end{array}$ & $\begin{array}{l}-1.011 \\
(-1.39)\end{array}$ & $\begin{array}{l}-1.809 \\
(-2.75)\end{array}$ & $\begin{array}{l}-2.675 \\
(-4.05)\end{array}$ \\
\hline $\begin{array}{l}\text { Exchange rate } \\
\text { Dummy: Freely Falling }\end{array}$ & $\begin{array}{l}-0.123 \\
(-0.20)\end{array}$ & $\begin{array}{l}0.647 \\
(0.93)\end{array}$ & $\begin{array}{l}0.094 \\
(0.14)\end{array}$ & $\begin{array}{l}-0.597 \\
(-0.96)\end{array}$ \\
\hline ICRG Economic Risk & $\begin{array}{l}-0.014 \\
(-0.95)\end{array}$ & $\begin{array}{l}-0.040 \\
(-2.76)\end{array}$ & $\begin{array}{l}-0.072 \\
(-4.85)\end{array}$ & $\begin{array}{l}-0.105 \\
(-6.05) \\
\end{array}$ \\
\hline ICRG Financial Risk & $\begin{array}{l}0.019 \\
(1.55) \\
\end{array}$ & $\begin{array}{l}0.028 \\
(1.53) \\
\end{array}$ & $\begin{array}{l}-0.022 \\
(-1.36) \\
\end{array}$ & $\begin{array}{l}\mathbf{0 . 0 3 3} \\
(2.43) \\
\end{array}$ \\
\hline ICRG Political Risk & $\begin{array}{c}-0.166 \\
(-16.89) \\
\end{array}$ & $\begin{array}{l}-0.091 \\
(-8.73) \\
\end{array}$ & $\begin{array}{c}-0.132 \\
(-15.05) \\
\end{array}$ & $\begin{array}{c}-0.103 \\
(-11.60) \\
\end{array}$ \\
\hline Historical returns & $\begin{array}{l}0.453 \\
(0.12) \\
\end{array}$ & $\begin{array}{r}16.189 \\
(3.12) \\
\end{array}$ & $\begin{array}{l}15.36 \\
(3.18) \\
\end{array}$ & $\begin{array}{l}-3.437 \\
(-0.85) \\
\end{array}$ \\
\hline Fund fixed effects & yes & Yes & yes & Yes \\
\hline Number of obs. & 23,696 & 20,113 & 25,379 & 25,844 \\
\hline Adj. $\mathrm{R}^{2}$ & 0.69 & 0.69 & 0.64 & 0.62 \\
\hline
\end{tabular}

Dependent variable: $\mathrm{w}_{\mathrm{ijt}}$. T-statistics in parentheses (based on robust standard errors, allowing for error clustering by countries). Regressions include fund fixed effects. Total number of countries: 16. 
Table 5. Tests of Differences in Means of Holdings

\begin{tabular}{|l|c|c|c|}
\hline & $\begin{array}{c}\text { Mean of difference } \\
\text { between actual and } \\
\text { MSCI weight for } \\
\text { Opacity Measure } \\
\text { below median } \\
\text { (MDLOW) }\end{array}$ & $\begin{array}{c}\text { Mean of difference } \\
\text { between actual and } \\
\text { MSCI weight for } \\
\text { Opacity Measure above } \\
\text { median (MDHI) }\end{array}$ & $\begin{array}{c}\text { Test that } \\
\text { H0: } \\
\text { MDLOW=MIDIHI } \\
\text { Against Ha: } \\
\text { MDLOW }>\text { MIDIHI } \\
\text { (p-value) }\end{array}$ \\
\hline OFACTOR & $\mathbf{0 . 3 3}$ & $\mathbf{- 0 . 1 6}$ & $\mathbf{0 . 0 0 0}$ \\
\hline MACROPOLICY OPACITY & $\mathbf{0 . 3 7}$ & $\mathbf{- 0 . 0 7}$ & $\mathbf{0 . 0 0 0}$ \\
\hline MACRODATA OPACITY & $\mathbf{0 . 4 8}$ & $\mathbf{- 0 . 2 5}$ & $\mathbf{0 . 0 0 0}$ \\
\hline CORPORATE OPACITY & $\mathbf{0 . 6 4}$ & $\mathbf{- 0 . 3 9}$ & $\mathbf{0 . 0 0 0}$ \\
\hline
\end{tabular}

Table 6. Investment Levels: Horserace Between Transparency Measures (additional control variables not reported)

\begin{tabular}{|l|c|c|}
\hline \multicolumn{1}{|c|}{ Opacity variable } & $\begin{array}{c}\text { Regression incl. only benchmark } \\
\text { weights as control variable } \\
\text { (as in Table 2) }\end{array}$ & $\begin{array}{c}\text { Regression incl. control variables } \\
\text { (as in Table 3) }\end{array}$ \\
\hline MACROPOLICY OPACITY & $\begin{array}{c}\mathbf{- 0 . 2 1 1} \\
\mathbf{( - 2 . 3 7 )}\end{array}$ & $\begin{array}{c}\mathbf{- 1 . 1 2 1} \\
\mathbf{( - 5 . 6 7 )}\end{array}$ \\
\hline MACRODATA OPACITY & $\begin{array}{c}\mathbf{- 0 . 3 4 5} \\
\mathbf{( - 2 . 1 8 )}\end{array}$ & $\begin{array}{c}\mathbf{1 . 9 6 4} \\
\mathbf{( 7 . 2 5 )}\end{array}$ \\
\hline CORPORATE OPACITY & $\begin{array}{c}\mathbf{- 0 . 9 8 6} \\
\mathbf{( - 5 . 3 1 )}\end{array}$ & $\mathbf{- 1 . 2 4 3}$ \\
\hline Number of obs. & 21,826 & 16,995 \\
\hline Adj. $\mathrm{R}^{2}$ & 0.66 & 0.77 \\
\hline
\end{tabular}

Table 7. Tests of Differences in Herding Means

\begin{tabular}{|l|c|c|c|}
\hline & $\begin{array}{c}\text { Mean Herding } \\
\text { (in \%) for Opacity } \\
\text { Measure Below } \\
\text { Median (MHLOW) }\end{array}$ & $\begin{array}{c}\text { Mean Herding (in \%) } \\
\text { for Opacity Measure } \\
\text { Above Median (MHHI) }\end{array}$ & $\begin{array}{c}\text { Test H0: } \\
\text { MHLOW=MHHI } \\
\text { Against Ha: } \\
\text { MHLOW }<\text { MHHI } \\
\text { (p-value) }\end{array}$ \\
\hline OFACTOR & $\mathbf{6 . 6}$ & $\mathbf{9 . 0}$ & $\mathbf{0 . 0 3}$ \\
\hline MACROPOLICY OPACITY & $\mathbf{6 . 7}$ & $\mathbf{8 . 7}$ & $\mathbf{0 . 0 8}$ \\
\hline MACRODATA OPACITY & 7.4 & 8.6 & 0.29 \\
\hline CORPORATE OPACITY & 7.1 & 8.6 & 0.11 \\
\hline
\end{tabular}


Table 8. Herding Regressions

\begin{tabular}{|c|c|c|c|c|}
\hline & OFACTOR & $\begin{array}{c}\text { MACROPOLICY } \\
\text { OPACITY }\end{array}$ & $\begin{array}{l}\text { MACRODATA } \\
\text { OPACITY }\end{array}$ & $\begin{array}{l}\text { CORPORATE } \\
\text { OPACITY }\end{array}$ \\
\hline Opacity Index & $\begin{array}{l}0.002 \\
(2.48)\end{array}$ & $\begin{array}{l}0.003 \\
(1.04)\end{array}$ & $\begin{array}{l}0.016 \\
(1.51)\end{array}$ & $\begin{array}{l}0.019 \\
(2.22)\end{array}$ \\
\hline Mean turnover & $\begin{array}{l}-0.061 \\
(-0.95) \\
\end{array}$ & $\begin{array}{l}-0.026 \\
(-0.34) \\
\end{array}$ & $\begin{array}{l}-0.074 \\
(-0.72) \\
\end{array}$ & $\begin{array}{l}0.023 \\
(0.44) \\
\end{array}$ \\
\hline $\begin{array}{l}\text { Mean market } \\
\text { capitalization }\end{array}$ & $\begin{array}{c}0.06 \\
(1.89) \\
\end{array}$ & $\begin{array}{l}0.149 \\
(2.90) \\
\end{array}$ & $\begin{array}{l}-0.007 \\
(-0.17) \\
\end{array}$ & $\begin{array}{l}\mathbf{0 . 0 9 0} \\
(2.49) \\
\end{array}$ \\
\hline Number of obs. & 30 & 26 & 37 & 31 \\
\hline $\mathrm{R}^{2}$ & 0.16 & 0.33 & 0.13 & 0.31 \\
\hline
\end{tabular}

Note: T-statistics (based on heteroskedasticity-robust estimates) are given in parentheses. Regressions also include a constant (not shown). Coefficients that are significant at the 5 percent level are marked bold.

Table 9. Reaction to News

\begin{tabular}{|c|c|c|c|c|}
\hline & OFACTOR & $\begin{array}{c}\text { MACROPOLICY } \\
\text { OPACITY }\end{array}$ & $\begin{array}{l}\text { MACRODATA } \\
\text { OPACITY }\end{array}$ & $\begin{array}{l}\text { CORPORATE } \\
\text { OPACITY }\end{array}$ \\
\hline $\begin{array}{l}\text { GDP forecast } \\
\text { Revision }\end{array}$ & $\begin{array}{l}0.460 \\
(1.98)\end{array}$ & $\begin{array}{l}0.375 \\
(4.70)\end{array}$ & $\begin{array}{l}0.321 \\
(4.42) \\
\end{array}$ & $\begin{array}{l}-0.499 \\
(-2.40)\end{array}$ \\
\hline $\begin{array}{l}\text { GDP forecast } \\
\text { revision } \\
\text {-OpacityIndex }\end{array}$ & $\begin{array}{l}-0.007 \\
(-2.17)\end{array}$ & $\begin{array}{l}-0.039 \\
(-2.87)\end{array}$ & $\begin{array}{c}-0.47 \\
(-7.84)\end{array}$ & $\begin{array}{l}0.090 \\
(2.32)\end{array}$ \\
\hline $\begin{array}{l}\text { GDP forecast } \\
\text { revision } \cdot \text { Mean turnover }\end{array}$ & $\begin{array}{c}3.73 \\
(11.85)\end{array}$ & $\begin{array}{l}1.414 \\
(4.78)\end{array}$ & $\begin{array}{c}3.46 \\
(11.42)\end{array}$ & $\begin{array}{c}3.389 \\
(11.38)\end{array}$ \\
\hline $\begin{array}{l}\text { GDP forecast } \\
\text { Revision } \cdot \text { Mkt cap. }\end{array}$ & $\begin{array}{c}0.58 \\
(2.62) \\
\end{array}$ & $\begin{array}{c}3.886 \\
(12.04) \\
\end{array}$ & $\begin{array}{c}1.64 \\
(6.88) \\
\end{array}$ & $\begin{array}{l}0.775 \\
(3.36) \\
\end{array}$ \\
\hline $\begin{array}{l}\text { GDP forecast } \\
\text { revision } \\
\text {-GDP per capita }\end{array}$ & $\begin{array}{c}-0.03 \\
(-8.41)\end{array}$ & $\begin{array}{l}-0.019 \\
(-3.12)\end{array}$ & $\begin{array}{c}-0.02 \\
(-7.88)\end{array}$ & $\begin{array}{l}-0.025 \\
(-8.18)\end{array}$ \\
\hline $\begin{array}{l}\text { GDP forecast } \\
\text { revision } \\
\text {-ICRG Pol. Risk }\end{array}$ & $\begin{array}{l}-0.003 \\
(-2.31)\end{array}$ & $\begin{array}{c}-0.019 \\
(-12.00)\end{array}$ & $\begin{array}{c}-0.01 \\
(-7.56)\end{array}$ & $\begin{array}{l}-0.003 \\
(-2.06)\end{array}$ \\
\hline $\begin{array}{l}\text { GDP forecast } \\
\text { revision } \\
\text {-ICRG Econ. Risk }\end{array}$ & $\begin{array}{l}-0.016 \\
(-4.59)\end{array}$ & $\begin{array}{c}-0.14 \\
(-4.31)\end{array}$ & $\begin{array}{l}-0.01 \\
(2.34)\end{array}$ & $\begin{array}{l}-0.013 \\
(-4.05)\end{array}$ \\
\hline $\begin{array}{l}\text { GDP forecast } \\
\text { revision } \\
\text {-ICRG Fin. Risk }\end{array}$ & $\begin{array}{c}0.02 \\
(6.91)\end{array}$ & $\begin{array}{c}0.039 \\
(13.32)\end{array}$ & $\begin{array}{c}0.03 \\
(\mathbf{1 0 . 9})\end{array}$ & $\begin{array}{l}0.026 \\
(9.47)\end{array}$ \\
\hline Fund fixed effects & Yes & Yes & Yes & Yes \\
\hline Country fixed effects & Yes & Yes & Yes & Yes \\
\hline No. of obs. & 53,763 & 45,897 & 56,469 & 59,231 \\
\hline $\mathrm{R}^{2}$ & 0.01 & 0.02 & 0.01 & 0.01 \\
\hline
\end{tabular}

The dependent variable is the change in country i's weight in fund j's portfolio at time $t$, minus the weight at time t$2: w_{i, j, t}-w_{i, j, t-2}$. Regressions include fund- and country fixed effects. T-statistics are given in parentheses (based on robust standard errors, allowing for error clustering within funds). 
Table 10. Reaction to News: Horserace Among Opacity Variables

\begin{tabular}{|c|c|}
\hline $\begin{array}{l}\text { GDP forecast } \\
\text { Revision }\end{array}$ & $\begin{array}{l}-1.614 \\
(-6.64)\end{array}$ \\
\hline $\begin{array}{l}\text { GDP forecast } \\
\text { revision } \\
\cdot \text { MACROPOLICY OPACITY }\end{array}$ & $\begin{array}{l}-0.144 \\
(-8.08)\end{array}$ \\
\hline $\begin{array}{l}\text { GDP forecast } \\
\text { revision } \\
\cdot \text { MACRODATA OPACITY }\end{array}$ & $\begin{array}{l}0.013 \\
(0.20)\end{array}$ \\
\hline $\begin{array}{l}\text { GDP forecast } \\
\text { revision } \\
\text {-CORPORATE OPACITY }\end{array}$ & $\begin{array}{l}0.494 \\
(9.03)\end{array}$ \\
\hline $\begin{array}{l}\text { GDP forecast } \\
\text { revision } \cdot \text { Mean turnover }\end{array}$ & $\begin{array}{l}0.094 \\
(0.20)\end{array}$ \\
\hline $\begin{array}{l}\text { GDP forecast } \\
\text { Revision } \cdot \text { Mkt cap. }\end{array}$ & $\begin{array}{c}4.994 \\
(11.70)\end{array}$ \\
\hline $\begin{array}{l}\text { GDP forecast } \\
\text { revision } \\
\text {-GDP per capita }\end{array}$ & $\begin{array}{l}-0.024 \\
(-3.75)\end{array}$ \\
\hline $\begin{array}{l}\text { GDP forecast } \\
\text { revision } \\
\text {-ICRG Pol. Risk }\end{array}$ & $\begin{array}{l}-0.010 \\
(-5.19)\end{array}$ \\
\hline $\begin{array}{l}\text { GDP forecast } \\
\text { revision } \\
\text {-ICRG Econ. Risk }\end{array}$ & $\begin{array}{l}-0.014 \\
(-4.29)\end{array}$ \\
\hline $\begin{array}{l}\text { GDP forecast } \\
\text { revision } \\
\text {-ICRG Fin. Risk }\end{array}$ & $\begin{array}{c}0.041 \\
(13.65)\end{array}$ \\
\hline Fund fixed effects & Yes \\
\hline Country fixed effects & Yes \\
\hline No. of obs. & 47,454 \\
\hline $\mathrm{R}^{2}$ & 0.03 \\
\hline
\end{tabular}

The dependent variable is the change in country i's weight in fund j's portfolio at time $t$, minus the weight at time t2: $w_{i, j, t}-w_{i, j, t-2}$. Regressions include fund- and country fixed effects. T-statistics are given in parentheses (based on robust standard errors, allowing for error clustering within funds). 
Table 11. Asian and Russian Crises: Fund flows and Opacity

\begin{tabular}{|c|c|c|c|c|c|}
\hline & OFACTOR & $\begin{array}{c}\text { MACROPOLICY } \\
\text { OPACITY }\end{array}$ & $\begin{array}{c}\text { MACRODATA } \\
\text { OPACITY }\end{array}$ & $\begin{array}{l}\text { CORPORATE } \\
\text { OPACITY }\end{array}$ & $\begin{array}{c}\text { Corp. Opacity: } \\
\text { LLSV } \\
\text { Accounting } \\
\text { Standards }\end{array}$ \\
\hline Opacity variable & $\begin{array}{r}-0.004 \\
(-1.85)\end{array}$ & $\begin{array}{c}-0.005 \\
(-4.40) \\
\end{array}$ & $\begin{array}{c}-0.01 \\
(-4.00)\end{array}$ & $\begin{array}{l}-\mathbf{- 0 . 0 0 7} \\
\mathbf{( - 3 . 4 2 )} \\
\end{array}$ & $\begin{array}{c}-0.008 \\
(-6.94) \\
\end{array}$ \\
\hline $\mathrm{R}^{2}$ & 0.04 & 0.05 & 0.04 & 0.04 & 0.05 \\
\hline Country random effects & Yes & Yes & Yes & Yes & Yes \\
\hline Fund fixed effects & Yes & Yes & Yes & Yes & Yes \\
\hline No. of countries & 27 & 26 & 34 & 30 & 22 \\
\hline No. of obs & 12,353 & 11,866 & 13,717 & 13,815 & 12,141 \\
\hline
\end{tabular}

Note: Dependent variable: Fund-level outflows by country over the period 97:05-98:09 divided by lagged assets in the respective country. Regressions include fund-fixed effects and country random effects. $Z$ statistics are given in parentheses. *Significant at the 10 percent level. LLSVaccounting standards=100-original accounting standard variable reported in LLSV.

Table 12. Asian and Russian Crises: Fund flows and Opacity, including Control Variables

\begin{tabular}{|c|c|c|c|c|c|}
\hline & OFACTOR & $\begin{array}{c}\text { MACROPOLICY } \\
\text { OPACITY }\end{array}$ & $\begin{array}{c}\text { MACRODATA } \\
\text { OPACITY }\end{array}$ & $\begin{array}{c}\text { CORPORATE } \\
\text { OPACITY }\end{array}$ & $\begin{array}{c}\text { Corp. Opacity: } \\
\text { LLSV } \\
\text { Accounting } \\
\text { Standards }\end{array}$ \\
\hline Opacity variable & $\begin{array}{l}0.001 \\
(3.18)\end{array}$ & $\begin{array}{l}-0.004 \\
(-2.67)\end{array}$ & $\begin{array}{l}-0.028 \\
(-6.78)\end{array}$ & $\begin{array}{l}-0.001 \\
(-0.15)\end{array}$ & $\begin{array}{l}-0.001 \\
(-4.48)\end{array}$ \\
\hline Turnover & $\begin{array}{l}-0.009 \\
(-0.36)\end{array}$ & $\begin{array}{l}-0.002 \\
(-0.09)\end{array}$ & $\begin{array}{l}0.137 \\
(4.03)\end{array}$ & $\begin{array}{l}0.054 \\
(2.15)\end{array}$ & $\begin{array}{l}\mathbf{0 . 0 5 9} \\
(2.43)\end{array}$ \\
\hline GDP per capita & $\begin{array}{l}0.000 \\
(0.27)\end{array}$ & $\begin{array}{l}0.003 \\
(3.79)\end{array}$ & $\begin{array}{l}0.001 \\
(2.81)\end{array}$ & $\begin{array}{l}0.001 \\
(1.66)\end{array}$ & $\begin{array}{c}0.00 \\
(0.00)\end{array}$ \\
\hline $\begin{array}{l}\text { ICRG Economic Risk } \\
\text { (lagged one month) }\end{array}$ & $\begin{array}{l}-0.006 \\
(-1.16)\end{array}$ & $\begin{array}{l}-0.003 \\
(-5.45)\end{array}$ & $\begin{array}{l}-0.002 \\
(-3.30)\end{array}$ & $\begin{array}{l}-0.002 \\
(-3.43)\end{array}$ & $\begin{array}{l}0.0001 \\
(0.28)\end{array}$ \\
\hline $\begin{array}{l}\text { ICRG Financial Risk } \\
\text { (lagged one month) }\end{array}$ & $\begin{array}{l}0.008 \\
(2.22)\end{array}$ & $\begin{array}{l}\mathbf{0 . 0 0 2} \\
(5.27)\end{array}$ & $\begin{array}{l}0.002 \\
(5.20)\end{array}$ & $\begin{array}{l}0.001 \\
(1.64)\end{array}$ & $\begin{array}{l}0.006 \\
(1.51)\end{array}$ \\
\hline $\begin{array}{l}\text { ICRG Political Risk } \\
\text { (lagged one month) }\end{array}$ & $\begin{array}{l}0.001 \\
(6.05) \\
\end{array}$ & $\begin{array}{l}\mathbf{0 . 0 0 1} \\
(2.73) \\
\end{array}$ & $\begin{array}{l}0.000 \\
(1.24)\end{array}$ & $\begin{array}{l}\mathbf{0 . 0 0 1} \\
(3.97) \\
\end{array}$ & $\begin{array}{l}0.000 \\
(0.07) \\
\end{array}$ \\
\hline $\mathrm{R}^{2}$ & 0.05 & 0.06 & 0.05 & 0.05 & 0.06 \\
\hline Country random effects & Yes & Yes & Yes & Yes & Yes \\
\hline Fund fixed effects & Yes & Yes & Yes & Yes & Yes \\
\hline No. of countries & 27 & 25 & 32 & 29 & 22 \\
\hline No. of obs & 10,758 & 10,153 & 11,735 & 12,008 & 10,572 \\
\hline
\end{tabular}

Note: Dependent variable: Fund-level outflows by country over the period 97:05-98:09 divided by lagged assets in the respective country. Regressions include fund-fixed effects and country random effects. $Z$ statistics are given in parentheses. *Significant at the 10 percent level. LLSVaccounting standards $=100$-original accounting standard variable reported in LLSV. 
Table 13. Asian and Russian Crises: Horserace Among Opacity indices

\begin{tabular}{|l|c|}
\hline MACRODATA & $\mathbf{- 0 . 0 3 5}$ \\
OPACITY & $\mathbf{( - 3 . 5 4 )}$ \\
\hline MACROPOLICY & $\begin{array}{l}0.004 \\
(1.32)\end{array}$ \\
\hline OPACITY & $\mathbf{- 0 . 0 1 2}$ \\
OPACITY & $\mathbf{- 1 . 7 2 )}$ \\
\hline Turnover & $\begin{array}{l}0.204 \\
(3.28)\end{array}$ \\
\hline GDP per capita & $\begin{array}{l}0.002 \\
(1.94)\end{array}$ \\
\hline ICRG Economic Risk & $\begin{array}{c}-0.002 \\
(-3.45)\end{array}$ \\
(lagged one month) & $\begin{array}{l}0.003 \\
(5.27)\end{array}$ \\
\hline ICRG Financial Risk \\
(lagged one month) & $\begin{array}{l}0.000 \\
(0.73)\end{array}$ \\
\hline $\begin{array}{l}\text { ICRG Political Risk } \\
\text { (lagged one month) }\end{array}$ & 0.07 \\
\hline R 2 & Yes \\
\hline Country random effects & Yes \\
\hline Fund fixed effects & 22 \\
\hline No. of countries & 9,037 \\
\hline No. of obs & \\
\hline
\end{tabular}

Note: Dependent variable: Fund-level outflows by country over the period 97:05-98:09 divided by lagged assets in the respective country. Regressions include fund-fixed effects and country random effects. $Z$ statistics are given in parentheses. *Significant at the 10 percent level. LLSVaccounting standards $=100$-original accounting standard variable reported in LLSV. 
Table A1. Opacity Measures

\begin{tabular}{|c|c|c|c|c|c|}
\hline COUNTRY & $\begin{array}{l}\text { O-FACTOR } \\
\text { (composite) }\end{array}$ & $\begin{array}{c}\text { MACRO } \\
\text { DATA } \\
\text { OPACITY }\end{array}$ & $\begin{array}{l}\text { MACRO } \\
\text { POLICY } \\
\text { OPACITY }\end{array}$ & $\begin{array}{l}\text { CORPOPRATE } \\
\text { OPACITY }\end{array}$ & $\begin{array}{c}\text { LLSV Accounting } \\
\text { OPACITY }\end{array}$ \\
\hline Argentina & 40 & 0.20 & 2 & 3.13 & 55 \\
\hline Bangladesh & . & 1.79 & . & . & . \\
\hline Botswana & . & 3.32 & . & . & . \\
\hline Brazil & 34 & 0.11 & 2 & 3.03 & 46 \\
\hline Chile & 23 & 0.62 & 2 & 2.20 & 48 \\
\hline China & & 1.87 & 7 & 4.23 & . \\
\hline Colombia & 39 & 1.27 & 3 & 3.57 & 50 \\
\hline Czech Rep. & 41 & 0.27 & 2 & 3.76 & . \\
\hline Ecuador & 42 & 0.55 & . & 5.06 & . \\
\hline Egypt & 39 & 1.81 & 6 & 3.66 & 76 \\
\hline Ghana & & 2.20 & . & & . \\
\hline Greece & 37 & 1.55 & . & 3.13 & 45 \\
\hline Hong Kong SAR & 29 & 1.94 & . & 2.18 & 31 \\
\hline Hungary & 31 & 0.35 & 2 & 3.23 & . \\
\hline India & 38 & 1.45 & 4 & 3.22 & 43 \\
\hline Indonesia & 47 & 0.71 & 4 & 3.83 & 65 \\
\hline Israel & 35 & 0.63 & 3 & 2.29 & 36 \\
\hline Jordan & . & 1.24 & 5 & 3.17 & . \\
\hline Kenya & 43 & 1.13 & . & . & . \\
\hline Korea & 42 & 1.00 & 3 & 3.25 & 38 \\
\hline Malaysia & . & 0.86 & 4 & 2.86 & 24 \\
\hline Mauritius & . & 2.91 & . & 3.14 & . \\
\hline Mexico & 33 & 0.32 & 3 & 3.36 & 40 \\
\hline Morocco & 34 & 1.59 & 4 & . & . \\
\hline Pakistan & 38 & 1.10 & 7 & . & 61 \\
\hline Peru & 38 & 0.46 & 3 & 3.39 & 62 \\
\hline Philippines & 37 & 0.38 & 3 & 3.40 & 35 \\
\hline Poland & 44 & 0.51 & 3 & 3.33 & . \\
\hline Portugal & . & 0.56 & . & 2.88 & 64 \\
\hline Romania & . & 0.41 & . & & . \\
\hline Russia & 55 & 0.34 & 5 & 4.21 & \\
\hline South Africa & 34 & 0.73 & 3 & 2.55 & 30 \\
\hline Singapore & 22 & 0.84 & . & 2.06 & 22 \\
\hline Slovak Rep. & 38 & 0.27 & . & 3.78 & . \\
\hline Sri Lanka & . & 1.12 & 6 & . & . \\
\hline Taiwan & 37 & & 4 & 2.59 & 35 \\
\hline Thailand & 42 & 0.51 & 5 & 3.75 & 36 \\
\hline Turkey & 46 & 0.50 & 5 & 2.89 & 49 \\
\hline Venezuela & 42 & 0.90 & 6 & 4.28 & 60 \\
\hline Zimbabwe & 46 & 1.40 & . & 3.17 & . \\
\hline
\end{tabular}


Figure 1. Mean Herding and Opacity

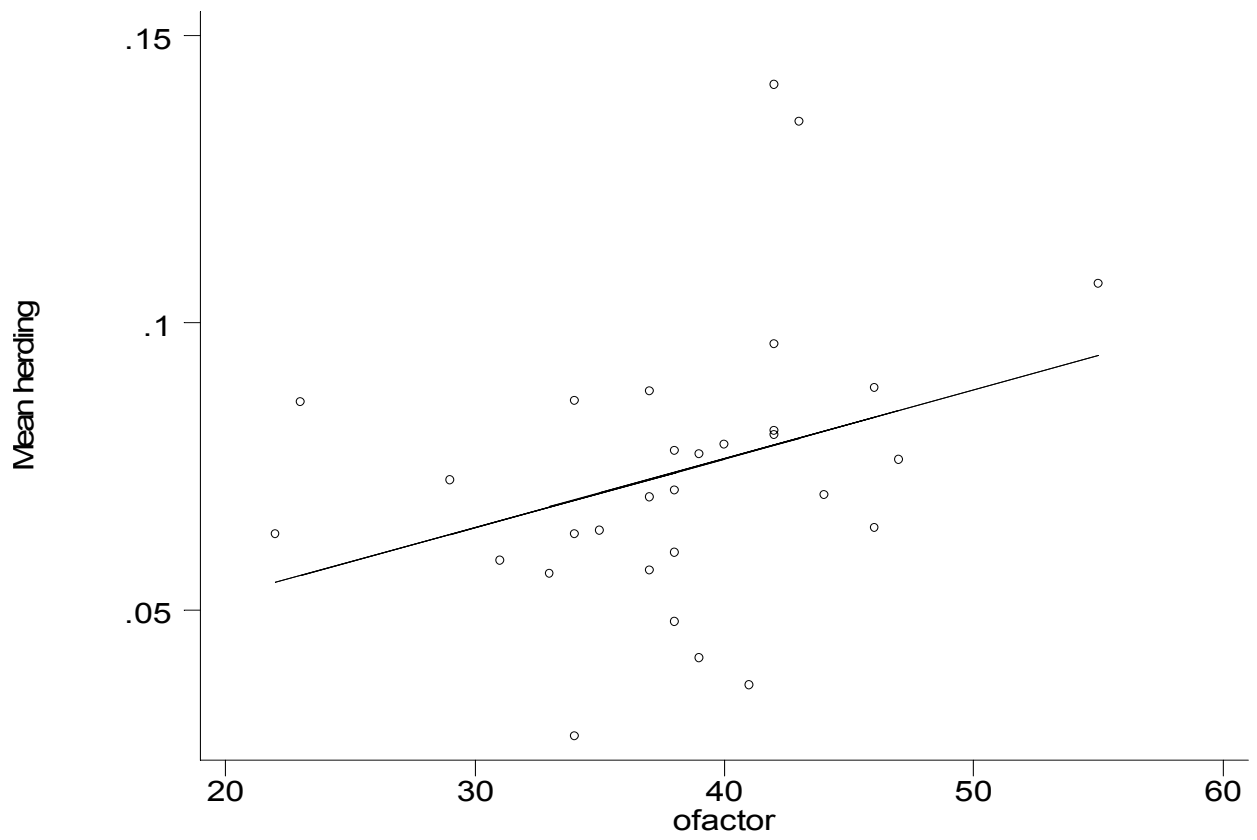

